\title{
Evaluation of the Sysmex XN-20 Complete Blood Count Analyser
}

Eun Jin Lee, Kwongu Lee, Miyoung Kim, Han-Sung Kim, Hee Jung Kang, and Young Kyung Lee Department of Laboratory Medicine, Hallym University College of Medicine, Anyang, Korea

Corresponding author: Young Kyung Lee Department of Laboratory Medicine, Hallym University Sacred Heart Hospital, Hallym University College of Medicine, 22 Gwanpyeong-ro 170beon-gil, Dongan-gu, Anyang 431-796, Korea

Tel: $+82-31-380-3930$

Fax:+82-31-380-3934

E-mail: lyoungk@hallym.or.kr
Background: The XN-20 (Sysmex, Japan) is a recently developed hematology analyser, which adopts new technologies to improve the accuracy of complete blood count (CBC) and white blood cell (WBC) differentials and the efficiency of the flag system. In this study, we evaluated the performance of the $\mathrm{XN}-20$ for $\mathrm{CBC}$, WBC differentials, and reticulocyte counts. We also analysed the efficiency of its flag system.

Methods: We evaluated the precision and linearity of $\mathrm{CBC}$ and reticulocyte counts. In the correlation study, the results of XN-20 were compared with those obtained using ADVIA 2120 (Siemens, USA). The performance was also evaluated in the 'low WBC mode.' We analysed the efficiency of the flag system in detecting abnormal blood cells using 43 abnormal samples.

Results: The CVs for precision were $<2 \%$ for most of the CBC parameters. Linearity was good for WBC, red blood cell (RBC), Hb, Hct, and platelet. The results of XN-20 were well correlated with those of ADVIA 2120. The correlation coefficients ( $r$ ) was $>0.9800$ for all CBC parameters except for erythrocyte indices, and it was $>0.9500$ for WBC differentials except for monocyte and basophil. In the 'low WBC mode', XN-20 could reliably analyse the WBC differentials in samples with low WBC count. The efficiencies of the flag systems were $95.3 \%$ for blasts, $83.7 \%$ for left-shifted neutrophils, $97.7 \%$ for atypical lymphocytes, and $86.0 \%$ for nucleated RBCs.

Conclusions: The XN-20 showed good precision and its results were well correlated with those obtained using ADVIA 2120. In particular, in the 'low WBC mode,' it could provide reliable WBC differentials for samples with low WBC counts, and the flag systems detected abnormal blood cells with high efficiency.

(J Lab Med Qual Assur 2014;36:140-148)

Key Words : Blood cell count, Leukocyte count, Differential leukocyte count

Received August 14, 2014, Revision received September 10, 2014, Accepted September 15, 2014

\section{서론}

전혈구계산(complete blood count, $\mathrm{CBC}$ )과 백혈구감별계 산은 대부분의 내원환자에서 기본적으로 시행되는 검사로, 가 장 기본적인 정보를 제공하지만, 한편으로는 진료방향을 결정 하는 데 있어 맨 처음으로 중요한 단서를 제공하는 검사이다 〔1]. 최근 개발되는 자동혈구계산기는 다양한 원리를 접목하 여 보다 정확하고 신속하게 결과를 제공하며, 더욱이 예전에는 검출하지 못하였던 모세포나 비정형 림프구, 유핵적혈구 등에 대한 정보도 제공하고 있어 환자진료에도 도움이 되고 검사실
업무의 효율성도 증대시키게 된다[1-4].

최근 개발된 XN-Series (Sysmex, Kobe, Japan)는 모듈형 태로 여러 대의 자동혈구계산기와 슬라이드 제작기를 연결하 여 사용하는 시스템이다. XN-20 (Sysmex)은 여기에 구성되 는 자동혈구계산기로 $\mathrm{CBC}$ 와 백혈구감별계산뿐만 아니라 망 상적혈구 수와 체액세포 수 측정기능도 추가로 가지고 있다. $\mathrm{XN}-20$ 은 전기저항원리 외에 비색법, 유세포분석원리(flow cytometry)를 추가로 이용하여 $\mathrm{CBC}$ 결과와 백혈구감별계산 의 정확성을 높이고, 다양한 지표들을 제공하며, 특히 저농도 백혈구 검체에서도 백혈구감별계산이 가능하게 하고, 비정상 
혈구 검출능력을 향상시키고자 하였다 $[5,6]$.

본 연구에서는 $\mathrm{XN}-20$ 의 $\mathrm{CBC}$ 와 백혈구감별계산능력을 평 가하고, 비정상혈구를 검출하는 flag체계에 대한 유효성을 분 석함으로써 XN-20의 자동혈구분석기로서의 수행능을 평가하 고자 하였다.

\section{재료 및 방법}

\section{1. 대상}

정밀도 분석을 위해서는 상품화된 대조물질인 XN-Check (Sysmex)를 사용하였으며, 각각 저농도, 정상농도, 고농도 3 가지 농도의 물질을 사용하였다. 상관성 비교를 위해서는 한림 대학교성심병원에 내원하여 $\mathrm{CBC}$ 가 의뢰된 검체 106검체를 대상으로 하였다. 망상적혈구 수의 상관성 분석을 위해서는 망 상적혈구 수가 높은 46검체를 별도로 이용하였다. 비정상혈구 를 검출하는 flag체계의 유효성을 보기 위해서 호중구증가증, 림프구증가증, 단구증가증, 호산구증가증, 호중구좌방이동, 비정형림프구, 유핵적혈구, 급성백혈병 등을 포함하는 43개 의 환자검체를 이용하였다. 환자 검체는 Dipotassium EDTA 진공채혈관(Becton, Dickinson and Company, Franklin Lakes, NJ, USA)에 채혈한 전혈을 이용하였다.

\section{2. 장비}

$\mathrm{XN}-20$ 은 전기저항원리와 광산란법과 더불어 유세포분석 원리를 이용한 자동혈구계산기로서 다양한 특수채널을 가지 고 있어 향상된 비정상혈구 검출기능과 세포계수기능을 제공 한다. 특히 $\mathrm{WDF}$ 채널은 미성숙백혈구를, $\mathrm{WPC}$ 채널은 모세포 나 비정형림프구를 검출할 수 있도록, WNR채널(white cell nucleated channel)은 유핵적혈구를 검출할 수 있도록 고안되 어 있고, 'low WBC 모드'에서는 백혈구 수가 낮은 검체에서 도 백혈구감별계산이 가능하도록, PLT-F 채널에서는 유세포 분석원리를 이용하여 저농도의 혈소판 수 측정 시 정확도를 높 이도록 제작되어 있다[5,6].

\section{3. 방법}

1) 정밀도

저농도, 정상농도, 고농도 3 가지 농도의 대조물질을 각 각 하루에 2 번씩 10 일간 측정하였고, 한 번 측정할 때 2 회 연 속 측정하였다. CLSI (Clinical and Laboratory Standards Institute) $\mathrm{EP} 05-\mathrm{A} 2$ [7]에 따라 검사 내 정밀도와 전체 정밀 도의 $\mathrm{CV}$ 를 산정하였다.

\section{2) 직선성}

동일한 혈액형의 검체 10 개를 혼주한 후 $3,000 \mathrm{rpm}$ 에서 15 분간 원심분리하여 적혈구층과 buffy coat 층을 분리하고, 다 시 $3,000 \mathrm{rpm}$ 에서 15 분간 원심분리하여 혈소판결핍혈장을 제 조하였다. 적혈구층과 buffy coat 층을 각각 혈소판결핍혈장으 로 계대희석하여 다양한 농도의 검체를 제조한 후 제조 당일 2 회씩 측정하여 평균값을 기대값과 비교하였다.

\section{3) 상관성}

상관성 평가는 $\mathrm{XN}-20$ 으로 측정한 결과를 기존에 검사실에 서 사용하고 있던 ADVIA 2120 (Siemens, Tarrytown, NY, USA)으로 측정한 결과와 비교하였다. 상관성 평가는 1 개월에 걸쳐 시행하였고, CLSI EP9-A3 [8]에 따라 4시간 이내에 수 행되었고 각 검사는 장비별로 1 회 시행하였다.

\section{4) Low WBC 모드를 이용한 백혈구감별계산}

백혈구 수가 매우 낮은 경우 low WBC 모드를 이용한 백혈 구감별계산 능력을 평가하기 위하여, $\mathrm{CBC}$ 검사가 의뢰된 다 양한 농도의 9 검체를 혈소판결핍혈장으로 각각 $1: 3$ 희석하고, 희석 전 검체와 희석 후 검체에 대해 시행한 백혈구감별계산 을 희석 전 검체에 대해 참고법인 수기법으로 시행한 백혈구감 별계산 결과와 비교하였다. 희석 전 검체의 백혈구 수는 0.4$20.5 \times 10^{9} / \mathrm{L}$ 였고 희석 후 검체의 백혈구 수는 $0.1-5.1 \times 10^{9} /$ $\mathrm{L}$ 였다. 수기법은 검체마다 2 개의 슬라이드를 제작하여 2 명의 검사자가 각각 서로 다른 슬라이드에 대해 각각 200 개의 백혈 구를 검사하여 백혈구감별계산을 시행하였으며, 두 검사자의 결과의 평균값을 구하였다[9].

\section{5) Flag의 분석}

$\mathrm{XN}-20$ 은 비정상 소견에 대해 다양한 flag를 표시하는데, 이 중 형태학적 이상과 관련된 주요 flag인 Blast flag, IG present flag, Left shift flag, Atypical lympho flag, NRBC present flag가 비정상 검체를 검출하는 데 있어 얼마나 유효 한 지를 1 개월동안 의뢰된 비정상 43 검체를 대상으로 평가하 였다. 각각의 flag는 CLSI H20-A2 [9]에 따라 슬라이드를 도 말하여 수기법으로 계수한 것을 참고법으로 하여 비교하였는 데, Blast flag는 모세포 $\geq 2 \%$ 인 경우, Atypical lympho flag 는 비정형림프구 $\geq 10 \%$ 인 경우 NRBC present flag는 유핵적 혈구 $\geq 1 / 100 \mathrm{WBCs}$ 인 경우를 참값으로 하여 비교하였고, IG present flag와 Left shift flag는 수기법에서 간상호중구, 후골 수구, 골수구, 전골수구가 $\geq 0.5 \%$ 인 경우를 참값으로 하여 비 교분석하였으며, 각각의 flag에 대한 민감도, 특이도, 양성 및 
Journal of LABORATORY MEDICINE and QUALITY ASSURANCE

Eun Jin Lee et al • Evaluation of the Sysmex XN-20

Table 1. The CVs of within-run precisions and total precisions for complete blood count parameters and reticulocyte counts

\begin{tabular}{lccccccccc}
\hline \multirow{2}{*}{ Parameter } & \multicolumn{3}{c}{ Low } & \multicolumn{3}{c}{ Normal } & \multicolumn{3}{c}{ High } \\
\cline { 2 - 9 } & Mean & $\begin{array}{c}\text { Within-run } \\
\text { CV }(\%)\end{array}$ & $\begin{array}{c}\text { Total CV } \\
(\%)\end{array}$ & Mean & $\begin{array}{c}\text { Within-run } \\
\text { CV }(\%)\end{array}$ & $\begin{array}{c}\text { Total CV } \\
(\%)\end{array}$ & $\begin{array}{c}\text { Mean } \\
\text { Within-run } \\
\text { CV (\%) }\end{array}$ & $\begin{array}{c}\text { Total CV } \\
(\%)\end{array}$ \\
\hline White blood cell $\left(\times 10^{9} / \mathrm{L}\right)$ & 3.0 & 1.97 & 2.21 & 6.9 & 1.40 & 1.56 & 16.5 & 0.98 & 0.97 \\
Red blood cell $\left(\times 10^{12} / \mathrm{L}\right)$ & 2.3 & 0.60 & 1.05 & 4.5 & 0.64 & 0.89 & 5.4 & 0.65 & 0.84 \\
Hb (g/dL) & 6.2 & 1.00 & 1.18 & 12.8 & 0.49 & 0.89 & 16.8 & 0.34 & 0.68 \\
Hct (\%) & 18.1 & 0.77 & 1.51 & 37.7 & 0.69 & 1.41 & 48.5 & 0.74 & 1.27 \\
Platelet $\left(\times 10^{9} / \mathrm{L}\right)$ & 45 & 4.49 & 6.58 & 249 & 2.61 & 2.71 & 567 & 1.50 & 1.38 \\
Reticulocyte $(\%)$ & 0.9 & 4.91 & 5.29 & 2.1 & 2.51 & 3.37 & 4.7 & 3.04 & 4.19 \\
\hline
\end{tabular}

음성예측도와 유효성(efficiency)을 구하였다. 유효성은 전체 검체 중에 flag체계가 진양성과 진음성을 보인 검체의 백분율 로 계산하였다.

\section{4. 통계}

통계분석은 MedCalc ver. 13.3.3.0 (Medcalc software bvba, Ostend, Belgium)을 이용하였다.

\section{결과}

\section{1. 정밀도}

$\mathrm{CBC}$ 와 망상적혈구 수의 검사 내 $\mathrm{CV}$ 와 전체 $\mathrm{CV}$ 는 Table 1 과 같다. $\mathrm{CBC}$ 는 대부분의 항목에서 $2 \%$ 미만의 $\mathrm{CV}$ 를 보였으 며, 혈소판의 경우 저농도 물질에서는 전체 $\mathrm{CV}$ 가 $6.58 \%$, 검사 내 CV가 $4.49 \%$ 였으나, 농도가 증가할 수록 CV는 감소하였으 며, 고농도에서는 전체 및 검사 내 $\mathrm{CV}$ 각각 $1.38 \%, 1.50 \%$ 였 다. 망상적혈구 수의 CV는 2.51-5.29\% 범위로 전체 농도 범 위에서 일관되게 양호한 값을 보였다(Table 1).

\section{2. 직선성}

직선성 평가에서 백혈구 수는 0.02-609.29 $\times 10^{9} / \mathrm{L}$, 적혈 구 수는 $0.02-8.70 \times 10^{12} / \mathrm{L}, \mathrm{Hb}$ 은 $0.2-26.1 \mathrm{~g} / \mathrm{dL}$, Hct은 0.2 $75.3 \%$, 혈소판 수는 $3.0-3,063.0 \times 10^{9} / \mathrm{L}$ 범위에서 모두 기대 값과 비교하여 상관계수(r) 0.9999 이상으로 우수한 직선성을 보였다(Fig. 1).

\section{3. 상관성}

$\mathrm{XN}-20$ 의 $\mathrm{CBC}$ 변수들은 $\mathrm{ADVIA} 2120$ 의 결과와 우수한 상 관성을 보였다. 백혈구 수, 적혈구 수, 혈소판 수, $\mathrm{Hb}, \mathrm{Hct}$ 은 모두 r값이 0.9800 이상이었고, 적혈구지수에서는 mean corpuscular volume (MCV), mean corpuscular hemoglobin
$(\mathrm{MCH})$, red cell distribution width는 r값이 0.9503?0.9713 범위였고, mean corpuscular hemoglobin concentration $(\mathrm{MCHC})$ 만 $\mathrm{r}$ 값이 0.8326으로 다소 낮았다. Mean platelet volume (MPV)는 r값이 0.7400이었다(Fig. 2A), 백혈구감별 계산에서 호중구, 림프구, 호산구는 r값이 0.9500 이상으로 높 은 상관성을 보였고, 단구와 호염기구는 각각 $0.5305,0.4750$ 의 r값을 보였다(Fig. 2B). 망상적혈구도 r이 0.9913으로 ADVIA 2120과 우수한 상관성을 보였다(Fig. 2C).

\section{Low WBC 모드를 이용한 백혈구감별계산}

희석 전 검체와 희석 후 검체에서의 백혈구감별계산(호중 구, 림프구, 단구) 결과를 희석 전 검체를 대상으로 참고방법 인 수기법으로 시행한 결과와 비교하였을 때 희석 후 검체도 희석 전 검체와 마찬가지로 양호한 r 값을 보였다(Fig. 3).

\section{Flag의 유용성 평가}

비정상 43검체를 대상으로 하여 XN-20에서 보고되는 Blast flag, IG present flag, Left shift flag, Atypical lympho flag, $\mathrm{NRBC}$ present flag의 유용성을 평가한 결과는 Table 2 와 같 다. Blast flag의 양성예측도는 $66.7 \%$, 음성예측도는 $100.0 \%$, 유효성은 $95.3 \%$ 였다. 미성숙백혈구를 검출하는 데 있어 Left shift flag의 양성예측도, 음성예측도, 유효성은 각각 $83.3 \%$, $83.8 \%, 83.7 \%$ 로, 각각 $38.5 \%, 80.0 \%, 67.4 \%$ 를 보인 IG present flag보다 높은 값을 보였다.

비정형림프구가 양성인 검체는 1 개 밖에 없었지만, Atypical lympho flag의 음성예측도와 민감도가 $100.0 \%$ 였으며, 유효성 도 $97.7 \%$ 로 비정형림프구를 선별하는 데 유용한 결과를 보였 다. NRBC present flag의 양성예측도는 $28.6 \%$ 로 낮았으나, 음성예측도와 특이도는 각각 $97.2 \%, 87.5 \%$ 로 우수한 값을 보 였으며, 유효성은 $86.0 \%$ 였다. 
A
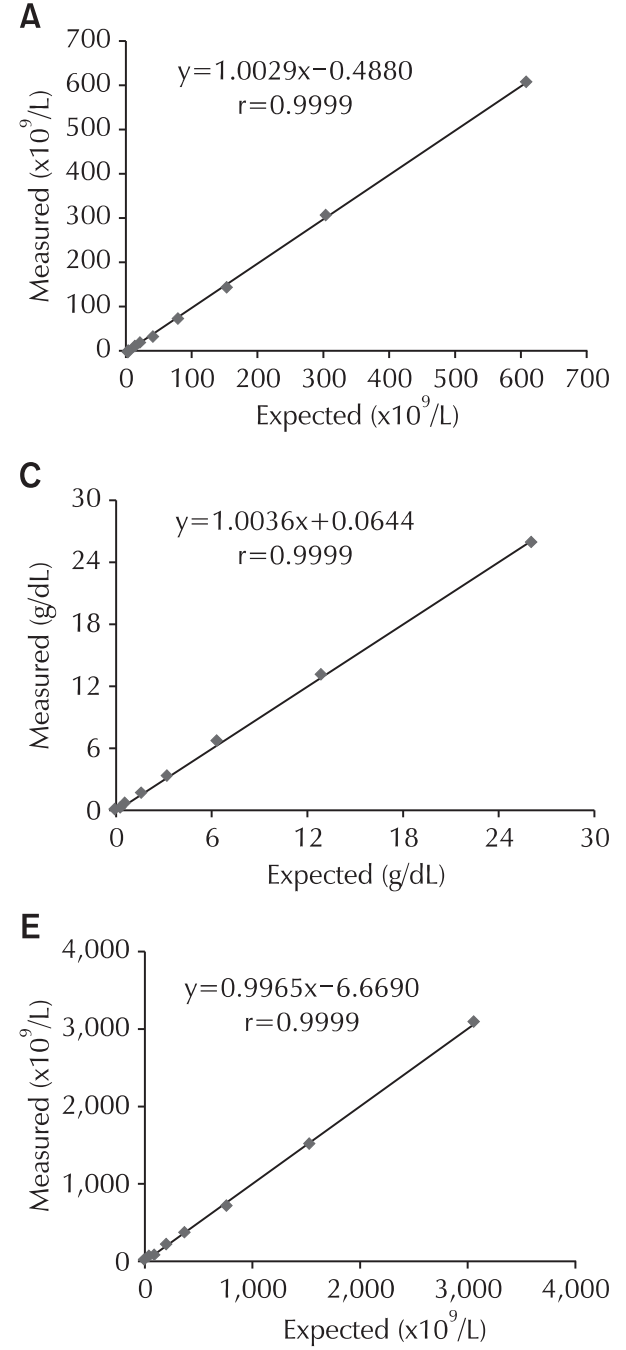

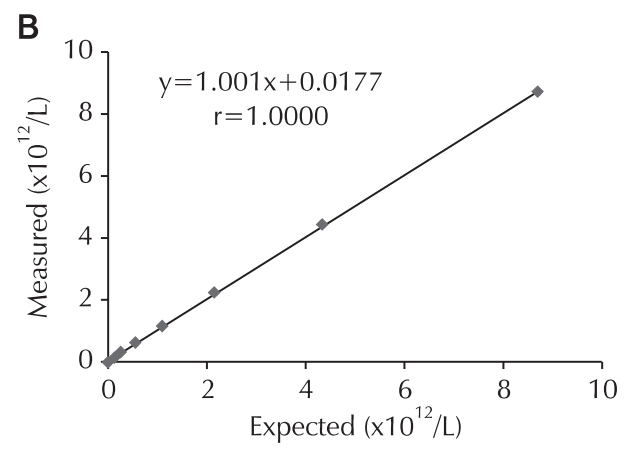

D

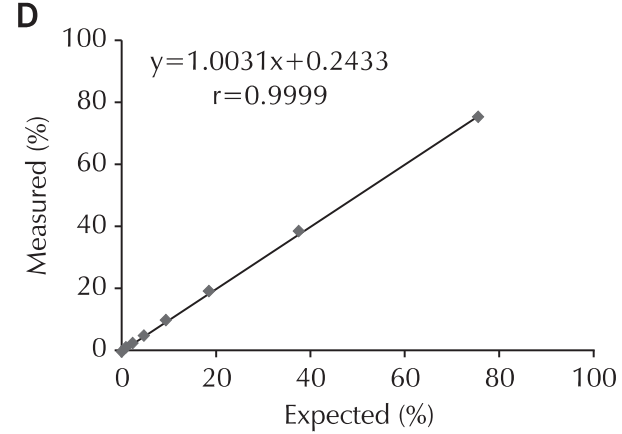

\section{고찰}

$\mathrm{XN}-20$ 은 $\mathrm{CBC}$, 5종 백혈구감별계산, 망상적혈구 수 및 유 핵적혈구 수 측정이 가능하고, 체액세포 수 측정기능도 가지고 있는 자동혈구분석기로 정밀도와 기존 방법과의 상관성이 우 수하였다.

$\mathrm{CBC}$ 검사에 대한 정밀도는 $\mathrm{CV}$ 값이 대부분 $2 \%$ 미만이었다. $\mathrm{CV}$ 값은 대조물질의 농도가 높을수록 낮은 값을 보였으며, 이 는 자동혈구분석기가 많은 수의 세포를 계산할수록 오차가 감 소한다는 견해와 일치하는 소견이었다[10]. 혈소판 수 측정에 있어서도 마찬가지로 평균 $45 \times 10^{9} / \mathrm{L}$ 농도에서는 전체 정밀도 $\mathrm{CV}$ 값이 $6.58 \%$ 였으나, 평균 $249 \times 10 \% / \mathrm{L}$ 농도에서는 $2.71 \%$ 였 으며, 평균 $567 \times 109 / \mathrm{L}$ 의 고농도에서는 $2 \%$ 미만의 값을 보였 다. 망상적혈구는 CV값이 2.51-5.29\%로 검체 내 망상적혈구 의 농도가 낮음을 고려할 때 전체 범위에서 고르게 양호한 결
과라고 생각한다.

직선성 평가에서는 $\mathrm{XN}-20$ 가 임상적으로 필요한 범위에 대 해 우수한 직선성을 보여 일반검사실뿐만 아니라 혈액질환자 의 검체를 다루는 검사실의 경우에도 정확한 정보를 제공할 수 있을 것으로 기대되었다.

본원에서 기존에 사용하고 있던 ADVIA-2120과 비교하였 을 때 $\mathrm{MCHC}$ 와 $\mathrm{MPV}$ 를 제외한 모든 지표들이 기존 장비와 양호한 상관성을 보였다. $\mathrm{MCHC}$ 의 낮은 상관성은 다른 자동 혈구분석기에서도 흔히 보이는 결과로, 적혈구지수를 측정하 는 방법이 광산란원리인지 전기저항원리인지 등의 원리에 따 라 $\mathrm{MCV}$ 에 영향을 주고, $\mathrm{MCV}$ 로부터 계산되거나 연관되어 있 는 $\mathrm{Hct}$ 와, $\mathrm{Hb}$ 으로부터 계산되는 $\mathrm{MCHC}$ 는 값의 범위가 좁아 더 크게 영향을 받는 것으로 여겨지진다[4,11]. 본 연구에서도 $\mathrm{XN}-20$ 은 전기저항법을 이용하고 ADVIA-2120은 광산란법을 이용하기 때문에 다른 적혈구지수에 비해 다소 낮은 상관성을 
A
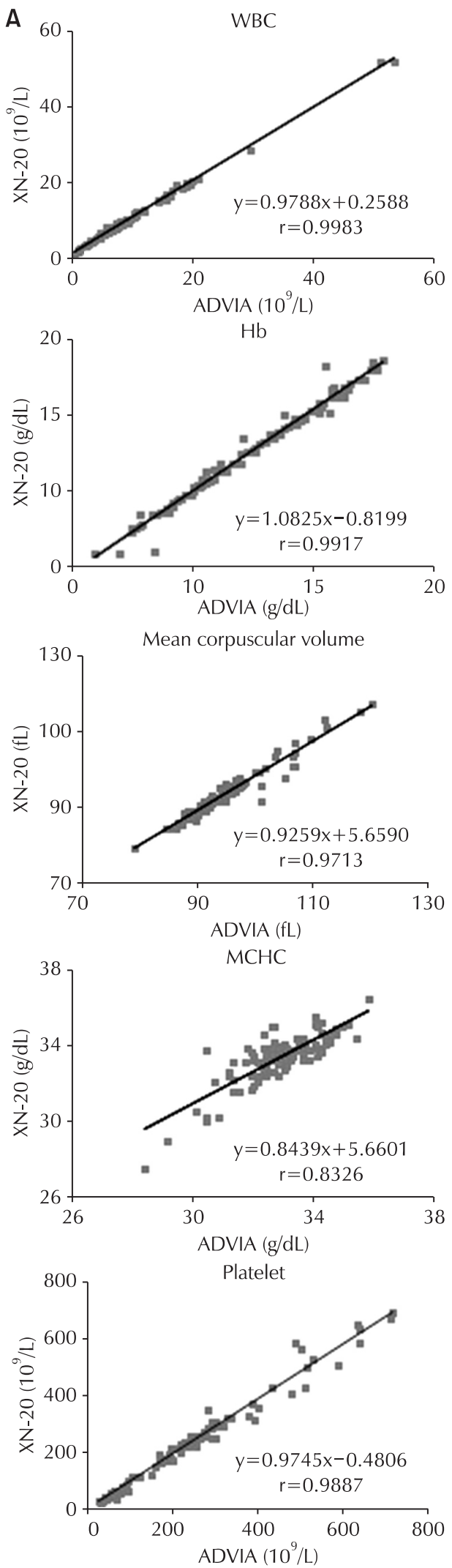
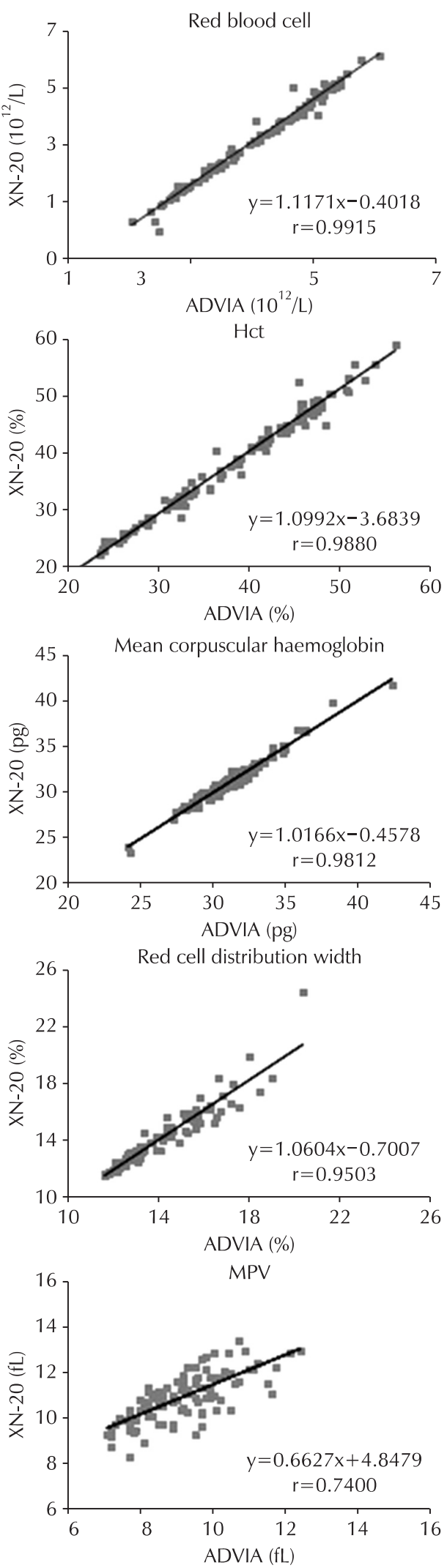

Fig. 2. Correlation between XN-20 (Sysmex) and ADVIA 2120 (Siemens) for: (A) complete blood count parameters $(n=106)$; (B) WBC differentials $(n=106)$; (C) reticulocyte counts $(n=46)$. Correlation coefficients were $>0.9500$ except for MCHC, $\mathrm{MPV}$, and monocyte and basophil. Abbreviations: WBC, white blood cell; RBC, Red blood cell; MCV, Mean corpuscular volume; $\mathrm{MCH}$, Mean corpuscular haemoglobin; RDW, Red cell distibution width; MCHC, mean corpuscular hemoglobin concentration; $\mathrm{MPV}$, mean platelet volume. 

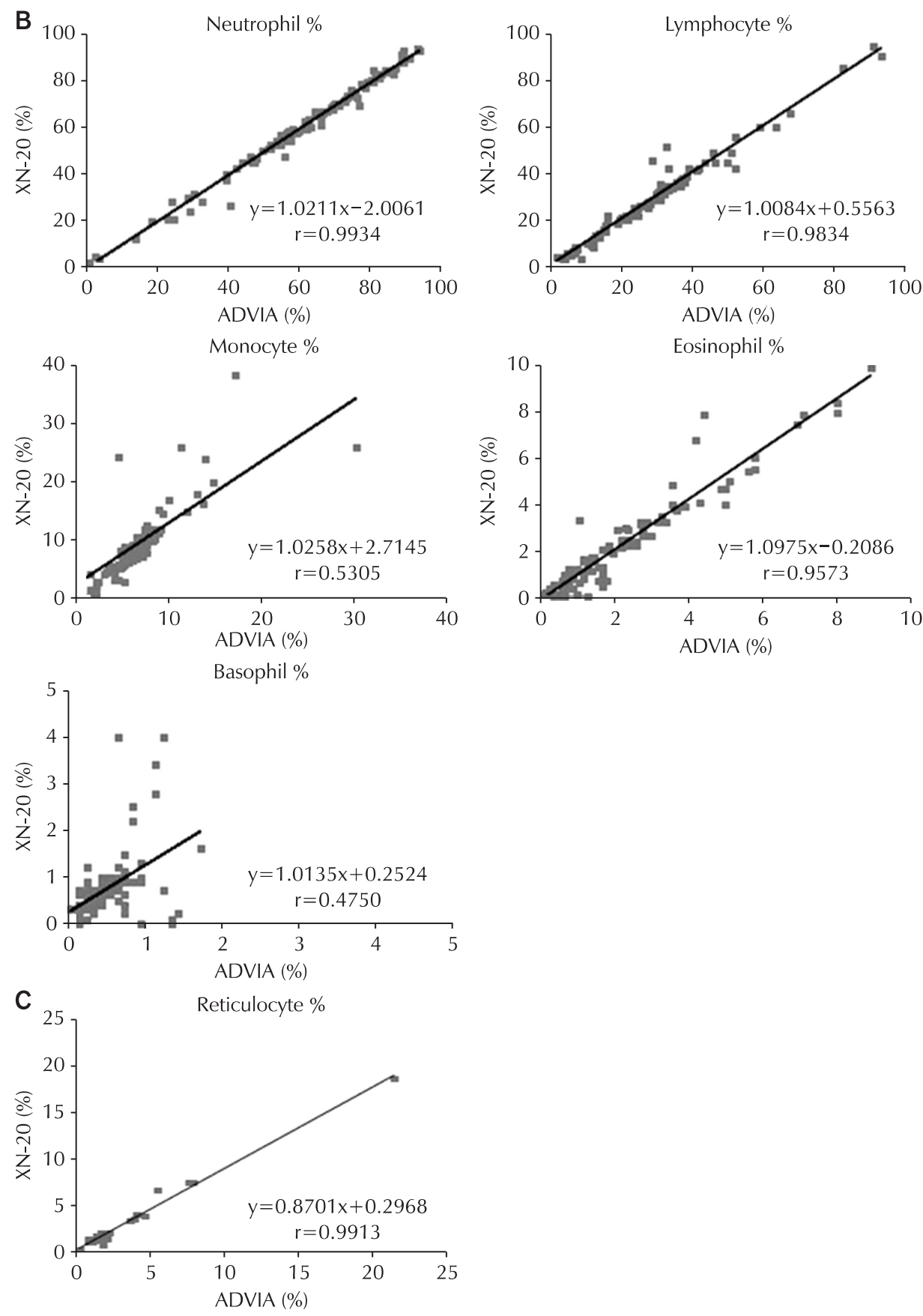

Fig. 2. Continued.

보였을 것으로 생각한다.

백혈구감별계산에서도 단구, 호염기구를 제외한 항목에서 기존 장비와 양호한 상관성을 보였다. 이는 다른 연구들과 비 슷한 결과로 단구와 호염기구의 경우 검체 내 농도가 낮은 것 이 주요 원인으로 생각한다[4,5].

$\mathrm{XN}-20$ 은 low WBC모드라는 기능을 통해 백혈구 수가 낮은 검체에 대해서도 비교적 신뢰할 수 있는 백혈구감별계산결과

를 제공할 수 있었다. 이는 백혈구 수가 낮은 검체에 대해 별도 로 수기법으로 백혈구감별계산을 시행하는 번거로움을 감소 시키기 때문에 검사실업무에 상당히 도움이 될 수 있다. 본 연 구에서 검체를 희석하여 인위적으로 백혈구 수를 낮춘 후 시행 한 백혈구감별계산결과가 원 검체로 시행한 수기법 감별계산 결과와 우수한 상관성을 보여, $\mathrm{XN}-20$ 가 백혈구 수가 낮은 검 체에서도 신뢰할 수 있는 백혈구감별계산결과를 제공하는 것 
A

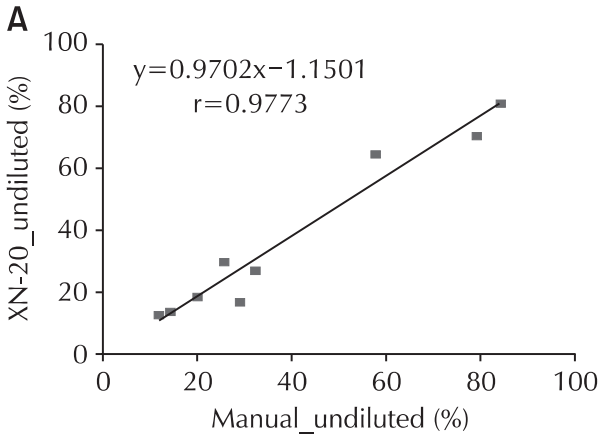

c
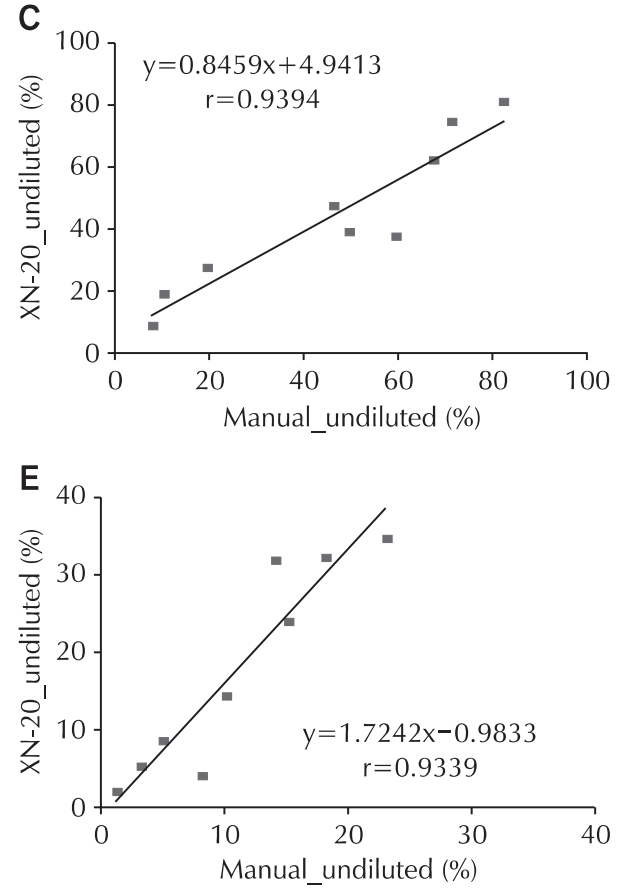
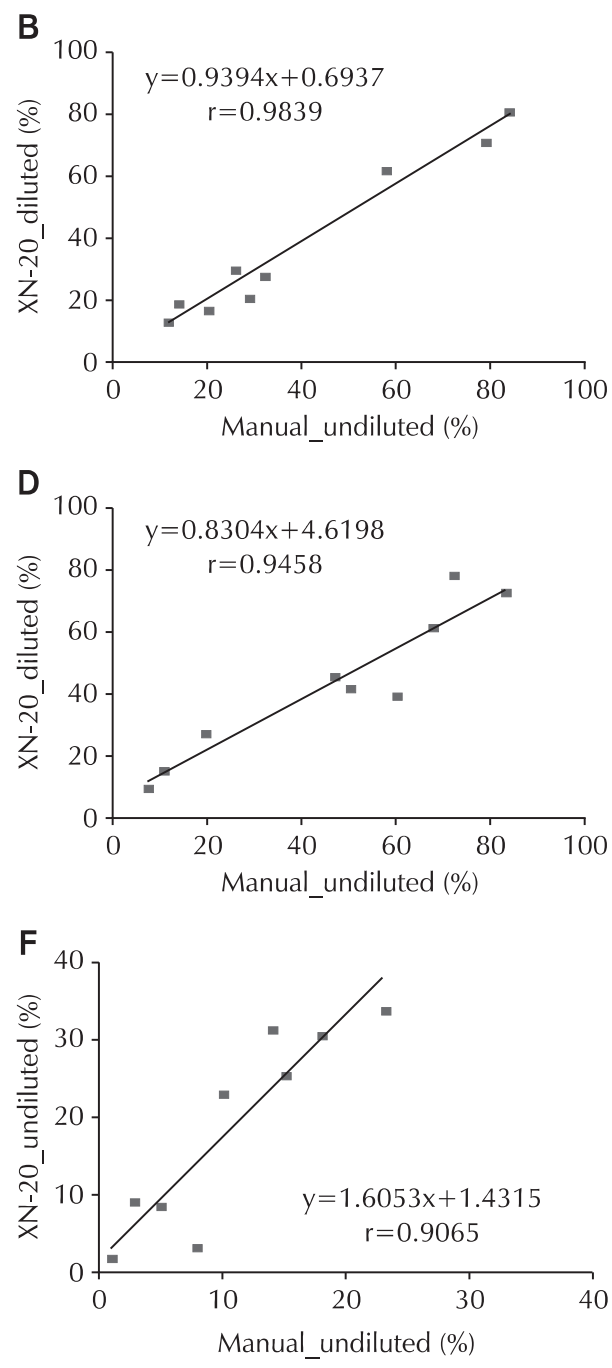

Fig. 3. White blood cell differentials of diluted samples were well correlated with those of manual differential counts of undiluted samples. (A, B) Neutrophil \%; (C, D) Lymphocyte \%; (E, F) Monocyte \%.

Table 2. The efficiency of the flag system for finding abnormal samples $(\mathrm{n}=43)$

\begin{tabular}{|c|c|c|c|c|c|c|}
\hline Flag & Blast $^{*}$ & IG present ${ }^{\dagger}$ & Left shift ${ }^{\dagger}$ & $\begin{array}{c}\text { IG present } \\
\text { shift }^{\dagger}\end{array}$ & $\begin{array}{l}\text { Atypical } \\
\text { lympho }\end{array}$ & NRBC present ${ }^{\S}$ \\
\hline True positive $(\mathrm{N})$ & 4 & 5 & 5 & 7 & 1 & 2 \\
\hline True negative $(\mathrm{N})$ & 37 & 24 & 31 & 23 & 42 & 35 \\
\hline False positive $(\mathrm{N})$ & 2 & 8 & 1 & 9 & 1 & 5 \\
\hline False negative $(\mathrm{N})$ & 0 & 6 & 6 & 4 & 0 & 1 \\
\hline Positive predictive value (\%) & 66.7 & 38.5 & 83.3 & 43.8 & 50.0 & 28.6 \\
\hline Negative predictive value (\%) & 100.0 & 80.0 & 83.8 & 85.2 & 100.0 & 97.2 \\
\hline Sensitivity (\%) & 100.0 & 45.5 & 45.5 & 63.6 & 100.0 & 66.7 \\
\hline Specificity (\%) & 94.9 & 75.0 & 96.9 & 71.9 & 97.6 & 87.5 \\
\hline Efficiency (\%) & 95.3 & 67.4 & 83.7 & 69.8 & 97.7 & 86.0 \\
\hline
\end{tabular}

${ }^{*}$ Blast $\geq 2 \%$. ${ }^{\dagger}$ Band form-promyelocyte $\geq 0.5 \%$. ${ }^{*}$ Atypical lymphocyte $\geq 10 \%$. ${ }^{5}$ Erythroblasts $\geq 1 / 100$ white blood cells. 
을 확인하였다.

정확한 flag는 검사실의 슬라이드 재검률을 낮출 수 있고 환 자를 진단하는 데도 도움이 된다[2,12]. 본 연구에서는 주로 flag에 의존하게 되는 비정상세포 관련 flag의 유용성을 평가 하였다. Blasts flag와 Atypical lympho flag는 위음성이 관찰 되지 않았으며, 유효성이 매우 높아 유용한 정보를 제공할 것 으로 기대되었다. 미성숙과립구의 존재를 표시하는 flag로 IG present flag와 Left shift flag 두 가지가 있었는데, 이 중 Left shift flag가 유효성이 더 높아 미성숙과립구 존재를 판단하는 데 더 유용한 flag라고 생각하였다. NRBC present flag는 위 양성이 높았으나 음성예측도가 높아 유핵적혈구 존재를 배제 하는 데 유용하게 사용할 수 있을 것이다.

$\mathrm{XN}-20$ 은 $\mathrm{CBC}$ 와 백혈구감별계산에 있어 정밀도와 기존 장 비와의 상관성이 우수하였고, 특히 백혈구 수가 낮은 검체에서 신뢰할만한 백혈구감별계산을 할 수 있는 장점이 있으며, 여러 가지 비정상 혈구를 검출할 수 있는 flag체계를 가지고 있어 일 반혈액검사실에서 유용하게 사용될 수 있을 것으로 생각한다.

\section{REFERENCES}

1. Buttarello M, Plebani M. Automated blood cell counts: state of the art. Am J Clin Pathol 2008;130:104-16.

2. Ward PC. The CBC at the turn of the millennium: an overview. Clin Chem 2000;46(8 Pt 2):1215-20.

3. Shelat SG, Canfield W, Shibutani S. Differences in detecting blasts between ADVIA 2120 and Beckman-Coulter LH750 hematology analyzers. Int J Lab Hematol 2010; 32(1 Pt 2):113-6.

4. Jo YA, Kim M, Kim HS, Kang HJ, Lee YK. Evaluation of the mindray BC-6800 complete blood counts analyzer. Lab Med Online 2013;3:131-7.

5. Briggs C, Longair I, Kumar P, Singh D, Machin SJ. Per- formance evaluation of the Sysmex haematology XN modular system. J Clin Pathol 2012;65:1024-30.

6. Tanaka Y, Tanaka Y, Gondo K, Maruki Y, Kondo T, Asai S, et al. Performance evaluation of platelet counting by novel fluorescent dye staining in the $\mathrm{XN}$-Series automated hematology analyzers. J Clin Lab Anal 2014;28:341-8.

7. Clinical and Laboratory Standards Institute. Evaluation of precision performance of quantitative measurement methods: approved guideline. 2nd ed. Wayne (PA): Clinical and Laboratory Standards Institute, 2004.

8. Clinical and Laboratory Standard Institute. Measurement procedure comparison and bias estimation using patient samples; approved guideline. 3rd ed. Wayne (PA): Clinical and Laboratory Standards Institute, 2013.

9. Clinical and Laboratory Standards Institute. Reference leukocyte (WBC) differential count (proportional) and evaluation of instrumental methods: approved standard. 2nd ed. Wayne (PA): Clinical and Laboratory Standards Institute, 2007.

10. Kang SH, Shin E, Ham CK, Kim HK, Cho HI. CELLDYN Sapphire hematology analyzer performance evaluation on leukocyte differential counts. J Lab Med Qual Assur 2006;28:219-24.

11. Yang HY, Park SY, Suh JT, Lee HJ. Evaluation of CELLDYN Sapphire hematology analyzer. J Lab Med Qual Assur 2008;30:189-94.

12. Kim SJ, Kim Y, Shin S, Song J, Choi JR. Comparison study of the rates of manual peripheral blood smear review from 3 automated hematology analyzers, Unicel DxH 800, ADVIA 2120i, and XE 2100, using international consensus group guidelines. Arch Pathol Lab Med 2012; 136:1408-13. 


\section{Sysmex XN-20 자동혈구분석기의 평가} 이은진 • 이권구 • 김미영 • 김한성 • 강희정 • 이영경 한림대학교 의과대학 진단검사의학교실

배경: XN-20 (Sysmex, Japan)은 전혈구계산(complete blood count, CBC)의 정확성을 높이고, flag체계의 유용성을 높이기 위해 새로운 기술을 도입한 자동혈구계산기이다. 본 연구에서는 $\mathrm{CBC}$, 백혈구감별계산, 망상적혈구 수 측정에 있어 XN-20의 성능과 flag체계의 유효성을 평가하고자 하였 다.

방법: $\mathrm{CBC}$, 망상적혈구 수 측정의 정밀도와 직선성을 분석하였다. 상관성 분석을 위해서는 XN-20 의 결과를 ADVIA 2120 (Siemens, USA)의 결과와 비교하였다. 'Low white blood cell (WBC) 모 드'의 기능에 대해서도 평가를 시행하였으며, 43 개의 비정상검체를 이용하여 비정상세포를 검출하는 데 있어 flag의 유효성도 평가하였다.

결과: 정밀도분석에서 $\mathrm{CV}$ 는 대부분 $\mathrm{CBC}$ 변수에서는 $2 \%$ 미만이었다. 직선성은 백혈구 수, 적혈구 수, 혈색소, 헤마토크릿, 혈소판 수 모두에서 우수한 결과를 보였다. XN-20의 결과는 ADVIA 2120 의 결과와 우수한 상관성을 보였다. 상관계수(r)는 적혈구지수를 제외한 $\mathrm{CBC}$ 지표에서 $>0.9800$ 였고 단구와 호염기구를 제외한 백혈구감별계산에서 $>0.9500$ 였다. Low WBC모드는 백혈구 수가 낮은 검체에서도 신뢰할만한 백혈구감별계산을 시행할 수 있었다. 각 flag의 유효성은 모세포를 검출하는 데 있어서는 $95.3 \%$, 미성숙과립구는 $83.7 \%$, 비정형림프구는 $97.7 \%$, 유핵적혈구는 $86.0 \%$ 였다.

결론: XN-20은 정밀도가와 기존 자동혈구분석기와의 상관성이 우수하였다. Low WBC모드는 백혈 구 수가 낮은 검체에서 신뢰할만한 백혈구감별계산결과를 제공하였으며, flag체계는 비정상세포를 검 출하는 데 상당히 유용하였다.

(J Lab Med Qual Assur 2014;36:140-148) 